Світлана НИЖНИК,

orcid.org/0000-0002-4777-8018

кандидат історичних наук,

директор наукової бібліотеки

Уманського національного

університету садівництва

(Украӥна, Умань)

cvetn@meta.ua

\title{
УМАНСЬКЕ УЧИЛИЩЕ САДІВНИЩТВА І ЗЕМЛЕРОБСТВА В ІСТОРЇ̈ ВІТЧИЗНЯНОЇ ОСВІТИ: ДО 175-РІЧЧЯ ЗАСНУВАННЯ УМАНСЬКОГО НАЦІОНАЛЬНОГО УНІВЕРСИТЕТУ САДІВНИЦТВА
}

\begin{abstract}
На основі методів історико-наукового аналізу, синтезу та узагальнення на иирокій документній законодавчій основі із залученням маловідомих архівних матеріалів висвітлено прочес становлення та діяльність Уманського училища садівництва і землеробства в 1859-1912 рр.

Історіографічний аналіз показав, щзо наявні праці недостатньо повно розкривають основні аспекти проблеми, яка досліджується. У результаті проведеного дослідження виділено основні етапи в його діяльності. Акиентовано увагу на високому рівні професійної підготовки випускників училища. Приділено увагу визначенню аспектів, які потребують подальшої наукової розробки з вказаної проблеми.

Ключові слова: аграрна освіта, сільське господарство, сільськогосподарська наука, Уманське училище садівництва, навчальна діяльність, Черкащчина.
\end{abstract}

\author{
Svetlana NYZHNYK, \\ Candidate of Historical Science \\ Director of the Research Library \\ Uman National University of Horticulture \\ (Ukraine, Uman) \\ cvetn@meta.ua
}

\section{UMAN SPECIALIZED SCHOOL OF HORTICULTURE AND AGRICULTURE IN THE HISTORY OF NATIONAL EDUCATION: DEDICATED TO THE 175TH ANNIVERSARY OF THE FOUNDATION OF UMAN NATIONAL UNIVERSITY OF HORTICULTURE}

Based on historical and scientific methods of analysis, synthesis and generalization of a broad-based documentary and legislative framework, involving little known archival materials the paper reveals the process of formation and activity of Uman Specialized School of Horticulture and Agriculture in 1859-1912. Three main stages of its activity are marked out in the result of the conducted research. High level of professional preparation of the School graduates is pointed out. Attention is devoted to defining the aspects that require further research development in the field of the study.

Historiographical analysis revealed that existent works on the subject do not bring out the main aspects of the problem to the full extent. Some scientists pay little attention to it in their studies in the context of other important problems of agricultural education.

Since mid 50s of the XIX century specialized agricultural educational institutions played a significant role in the development of agricultural education in Ukraine. The median level of agricultural education was presented by three vocational schools of agriculture, among which Uman School became not only the educational center but also the base for practical and theoretical research.

A prominent hub of technical training of people's teachers was the Main School of Gardening (Uman Specialized School of Horticulture and Agriculture (1868-1921), Uman National University of Horticulture at present), the first higher educational institution of horticulture in Russia.

Attention is paid to the legislation, that regulated the activity of agricultural educational institutions including Uman School. Reasons for reorganization of the educational institution by government authorities were studied. Periodization of reorganization of the educational institution are distinguished. Changes in programs, education plans, practicals and in the economic complex of Uman School are considered on the ground of documentation 
With considerable practical training the school always honored its duty providing professional preparation of "scholars of management". A group of highly skilled lecturers was gradually formed in Uman Specialized School of Horticulture and Agriculture. In particular, V. V. Pashkevych, V.O. Pohhenpol, D.S. Levanda, A.M. Ro, P.H. Shytt, V.I. Edelshtein, I.I. Korablov and others.

Uman Specialized School of Horticulture and Agriculture, as a specialized institution of secondary agricultural education, has undergone a complex path of its development, including several reorganizations and restructuring in the educational and practical structure. However, the most important feature of this system was the training of highly qualified gardening specialists. For high indicators in scientific and agricultural activities, exemplary exhibits, Uman Specialized School of Horticulture and Agriculture has repeatedly (over the years) been awarded the Gold Medal, Big Silver and Bronze Medals, honorary references, certificates of recognition and other awards.

Attention is devoted to defi ning the aspects that require further research development in the fi eld of study.

Key words: agricultural education, agriculture, agricultural science, Uman horticultural colleg, studies,

Cherkasy region.

Постановка проблеми. Історія розвитку будь-якої держави безпосередньо пов’язана 3 наукою та освітою, що є чи не найважливішими чинниками економічного зростання та суспільно-політичного становлення країни. В Україні серед всіх наук чільне місце займають сільськогосподарські. Освіта є лише однією з соціальних ознак суспільства, але не менш важливою, ніж побутові умови, заняття, прибутки, виробництво та інше. Питання історії створення та розвитку сільськогосподарських освітніх закладів, наукових установ завжди було важливим і актуальним, тим більше таким воно є нині, в час відродження національного виробництва, у тому числі й сільськогосподарського.

Аналіз діяльності сільськогосподарських освітніх закладів Черкащини, внесок вчених-викладачів регіону в наукову сферу та підвищення аграрної культури має суттєве значення для відтворення історії вітчизняної аграрної науки, вдосконалення професійної підготовки спеціалістів галузі в сучасних умовах. Звернення до історії розвитку аграрної освіти дає можливість проаналізувати здобутки сучасності, порівняти досягнення освіти з викликами цивілізаційних зрушень. Ознайомлення 3 історико-педагогічною спадщиною нашого міста в умовах формування нової системи освіти молоді набуває особливої актуальності, тому що історія розвитку освіти в м. Умань відтворює всі історичні події, що сталися в Україні протягом кількох століть.

За останнє десятиліття в Україні відбулися зміни в науці та суспільній свідомості, які привели до необхідності переосмислення науки і освіти, а також їх цілей i завдань. Адже якісну освіту сучасного фахівця будь-якої галузі 
неможливо уявити без розвитку інформаційної, дослідницької та комунікативної культури. Зрозуміло, що реформувати аграрну освіту окремо від усієї української освіти не можна, бо процеси інтеграції нині набагато глибші. Аграрні вузи давно готують фахівців не тільки із сільськогосподарських спеціальностей, а конкурують із будівельними, технічними й, навіть, юридичними, економічними вузами.

Аналіз досліджень. В українській історіографії недостатньо наукових праць, у яких би на широкому фактичному матеріалі розкривалася діяльність Уманського училище садівництва і землеробства у другій половині XIX початок XX ст. Наукові розвідки не мали узагальнюючого характеру та відзначались епізодичністю й фрагментарністю. Аналіз історіографії засвідчує, що окремі аспекти зазначеної теми знайшли наукове висвітлення (Власюк, 1941: 68), (Карасюк, 1994: 18), (Костюк, 2005: 32), (Сафронов, 1910: 80), але в цілому вона залишається перспективною в плані іï вивчення.

Мета статті. Більш повне висвітлення історії становлення та розвитку Уманського училища садівництва і землеробства, визначення основних етапів в його діяльності, реорганізацій та змін у навчально-практичній структурі.

Виклад основного матеріалу. Переважна більшість українських земель входила до складу Російської імперії. Відповідно історія виникнення сільськогосподарських навчальних закладів в Україні тісно пов'язана 3 розвитком аграрної освіти в Росії.

3 середини 50-х pp. XIX ст. значну роль у розвитку аграрної освіти і науки України починають відігравати спеціалізовані сільськогосподарські училища. Середній рівень сільськогосподарської освіти був представлений трьома професійними сільськогосподарськими навчальними закладами (Харківським, Уманським та Херсонським училищами Міністерства Державного Майна), серед яких виділялося Уманське училище, що стало не лише центром освіти, а й базою для проведення практичних і теоретичних досліджень. 
У другій половині XIX - на початку XX ст. аграрні вищі навчальні заклади перебували у підпорядкуванні різних міністерств та відомств, не існувало чіткої організації управління ними, типових навчальних планів і програм, а також конкретно визначених рівнів кваліфікації спеціалістів.

У 30-х роках XIX ст. в поміщицьких маєтках широко розвиваються прибуткові галузі сільського господарства, як зразкові сади, тутові плантації, пасіки. Для реалізації та обслуговування цих галузей на кінець XIX ст. в царській Росіі діяло 6 середніх сільськогосподарських навчальних закладів, 3 яких два (Уманська та Харківська школи) знаходилися в Україні.

Значним осередком професійного навчання народних учителів стало Головне училище садівництва (Уманське училище землеробства і садівництва (1868-1921), нині - Уманський національний університет садівництва) перший в Росії вищий навчальний заклад з садівництва.

Головне училище садівництва було відкрите 9 серпня 1844 р. у м. Одесі при Імператорському Ботанічному саду на основі «Положення про садові заклади», затвердженого царським указом від 9 лютого 1842 р. (Сборник, 1899: 27). На його утримання держава щорічно виділяла 10 тис. крб. сріблом. Першими учнями училища стали десять вихованців Одеського сирітського будинку, які навчалися за казенний кошт. В училищі працювало 8 викладачів, які вели 16 предметів. Навчально-виробничу практику учні проходили в Криму та в Одеському Ботанічному саду. У різний час в Одеському училищі було від 18 до 29 учнів. У 1857 р. кількість учнів зменшилась до 12, а в 1858 р. їх було всього 8 (Сафронов, 1910: 44).

3 початку своєї діяльності Головне училище садівництва розвивалося в несприятливих умовах, які полягали в: обмеженості оборотних коштів для успішного розвитку навчальної та науково-практичної роботи, недостатності відповідних наукових кадрів садівництва та робочої сили i, врешті, природних умовах - засушливому кліматі Одеси без можливості правильного зрошування різноманітних насаджень ботанічного саду. 
У 1859 році з Одеси до Умані було переведено (в Царицин сад «Софіївку») Головне училище садівництва, яке діяло на базі Одеського ботанічного саду з 1844 року.

Перехід училища в Умань співпав з активізацією суспільного життя в країні, що, звичайно, відобразилося і на піднесенні освіти. Після падіння кріпосного права відбувся перехід до нових форм сільського господарства, з'явився великий попит на землеробів, а садівництво відсувалося на другий план. Відповідно до нових умов життя, попиту на вчених-садівників майже не було, а лише - на практичних садівників (недорогих з жалуванням до 150 крб.), тому випускники училища не знаходили собі місця роботи, де б могли практично примінити свої знання і змушені шукати собі іншу діяльність: управляючих маєтками та прикажчиками, куди їх залюбки запрошували..

Зі скасуванням кріпосного права 1861 р. у Росії відбулися значні соціально-економічні реформи, що зумовили зміни в системі аграрної освіти. Зокрема, Уманське Головне училище реорганізоване в Уманське середнє училище землеробства і садівництва (1868-1903).

Перетворення відбулося Уманського училища в Училище землеробства та садівництва зі значним розширенням програм, при чому навчальна система училища зближувалась з навчальною системою інших землеробських училищ, але широким вивченням садівництва (Сборник, 1900: 169].

Типових навчальних програм для вищих аграрних навчальних закладів України у другій половині XIX - на початку XX ст. не існувало, тому у більшості випадків, складаючи їх використовувався досвід собі подібних.

Навчальні плани аграрних навчальних закладів складались з предметів, які можна поділити на три групи: загальні, допоміжні і спеціальні.

У 1870 р. Департаментом землеробства розроблено нові програми для землеробських училищ, які передбачали значне розширення вивчення природничих наук і сільськогосподарських дисциплін протягом п’ятирічного строку навчання. Введення цих програм в м. Умані (1872) привело до створення новового типу училища, в якому землеробство тісно поєднувалося 3 
садівництвом в одній спеціальності. Поряд з викладанням у повному обсязі садівництва вводилися дисципліни, що вивчалися у землеробських училищах країни: повний курс землеробства, геодезія, рослинництво, тваринництво, сільськогосподарська економія з рахівництва, сільськогосподарська технологія, вчення про землеробські машини і знаряддя з викладенням підстав механіки, сільського будівельного мистецтва і короткого викладу законів, необхідних для хлібороба.

Переповнення землеробських училищ вихованцями виникла необхідність створення розпорядження про обмеження прийому учнів у ці заклади. Згідно «Положення про землеробські училища» (30 травня 1878 р.) вони були зрівняні 3 реальними училищами. Як результат, протягом 1879-1894рр. у землеробських училищах навчалось: Уманському - 556, Маріїнському - 550, Казанському - 428, Московському - 899 осіб. Станом на 1875 рік в Уманському училищі землеробства і садівництва за походженням сімей навчались: дворян 38 , офіцерських дітей - 52, діти осіб духовного звання -21 , почесних громадян -5 , купців -8 , іноземців - 2, міщан - 28, селян - 13.

Після завершення 6-річного строку навчання в училищі учні, що закінчували повний курс на «відмінно», одержували атестат 1 класу і звання «почесного громадянина». Згодом, після трирічної роботи в сільському господарстві, їм присвоювали звання «ученого управителя і садівника». Всі інші учні, що витримали випускні екзамени, одержували атестат II класу, при додержанні тих самих умов їм присвоювали звання «помічника ученого управителя - садівника». Звання «ученого управителя» цій категорії випускників присвоювала Рада училища після трирічної роботи в землеробстві й садівництві.

Програма теоретичного курсу садівництва залишалась у попередньому стані, а практичні заняття були значно скорочені через те, що більша частина літнього часу приділялась практичним заняттям з сільського господарства, для чого було влаштоване при училищі невелике практичне поле площею 43 десятини. 
Внаслідок перетворення Уманського училища в землеробське, відбулося роздвоєння навчальної системи на дві спеціальності, де прослідковувалась цілковита невідповідність між теорією та практикою. Сумісництво двох спеціальностей сприятливих результатів не дало.

Після закінчення повного курсу навчання відмінники отримували атестат першого розряду та звання почесного громадянина. Після роботи в сільському господарстві протягом трьох років, їм присвоювали звання «ученого управителя і садівника». Всі інші учні, що витримали випускні іспити, одержували атестат другого розряду, при тих же умовах їм присвоювалося звання «помічника ученого управителя і садівника» (Устав, 1895: 188). Звання «ученого-управителя» такі випускники отримували після семирічної практики у господарстві (Статут §39. Положення ст. 18). Учням, які не закінчили повного курсу, але навчалися не менше як два роки та витримали іспити 3 усіх сільськогосподарських та садових робіт, присвоювалось звання «нарядчиків сільських та садових робіт» (Статут §38. Положення ст. 17). Учні, що отримали атестат першого розряду, могли вступати на державну службу Міністерства Державного Майна на посади інспекторів, вчителів креслення, геодезії та лаборантів у землеробських училищах, конторників або помічників управителів сільськогосподарськими фермами (Статут §42. Положення ст. 21).

За півстоліття училище випустило 462 учнів, 3 них Головне училище садівництва (тобто до 1868 р. включно) закінчили 66 осіб (29 в Одесі, 37 в Умані), а решта 395 осіб закінчили Уманське училище землеробства i садівництва (177 осіб до перетворення у 1878 р. і 218 - після перетворення) (Сафронов, 1910: 21). Таким чином, щорічно випускалося приблизно 9 осіб. Головне училище садівництва зробило всього 14 випусків, а училище землеробства та садівництва - 23 (до 1894).

За 1868-1903 pp. Уманське училище землеробства i садівництва випустило 540 «вчених управителів і садівників». Протягом вказаного періоду в Умані було створено новий тип училища, в якому землеробство тісно поєднувалося 3 садівництвом в одній спеціальності. Таке поєднання було 
незручним і спричиняло багато труднощів в організації навчально-практичного процесу училища. Уманське училище забезпечувало потреби величезного району та булоєдиним для всього Південно-Західного краю з високоякісним та різнобічним господарством. В

При значній практичній підготовці училище завжди з честю виконувало свій обов'язок: випускало добре підготовлених «учених управителів». Поскільки училище розміщувалося в саду, який був гордістю всього ПівденноЗахідного краю, то поза сумнівом, що жоден навчальний заклад в імперії не мав таких могутніх засобів для розвитку естетичного смаку у своїх вихованців, як училище землеробства і садівництва. Цією виключною обставиною необхідно було скористатися для посилення викладання садівництва. Ставилося питання про перетворення цього училища виключно в садівниче. 3 цього приводу в тогочасних газетах і журналах друкувалися статті, в яких приводилися аргументи проти задуманої реформи, висловлювалася думка про з'єднання обох спеціальностей, але з необхідним відокремленням кожної, з метою підготовки висококваліфікованих спеціалістів (Сборник, 1900: 726).

Основний контингент учнів складався переважно з вихідців Київської, Подільської, Волинської та Полтавської губерній, тобто училище задовольняло в основному місцеві потреби в спеціалістах. Проте в училищі також навчалися учні з віддалених губерній, як то: Привіслинських, Закавказьких, Таврійської, Бессарабської, Чернігівської, Курської, Катеринославської, Харківської та області Війська Донського (Сборник, 1899: 81].

В Уманському училищі землеробства і садівництва поступово склався контингент висококваліфікованих викладачів. Зокрема, В. В. Пашкевич викладав ботаніку та садівництво (1885-1892), завідував Уманським Царициним Садом. Період роботи в Училищі особливо цінував, називаючи його початковим етапом у своїй науково-педагогічній роботі. Колезький радник, кандидат наук, інспектор по землеробству М. К. Васильєв читав курс рослинництва і здійснював керівництво практикою із землеробства, рослинництва, космографії та мінералогії, проводить дослідження з обробітку 
грунту та його удобрення в умовах Умані. Колезький асесор Ю.Р. Ланцький головний садівник Царициного саду, інспектор по садівництву - читав по сумісництву курс садівництва. Статський радник Д.С. Леванда викладав бухгалтерію, інспектор училища статський радник В.О. Поггенполь - хімію, фізику й метеорологію та ін.

Результати наукової роботи викладачів та учнів Уманського училища землеробства і садівництва демонструвалися на I Сільськогосподарській виставці Київського товариства сільського господарства (м. Київ,1883), I Міжнародній виставці садівництва (м. Санкт-Петербург, 1884), Всеросійській сільськогосподарській виставці (м. Харків, 1887), IV Всеросійській сільськогосподарській виставці (м. Харків, 1888), Міжнародній виставці садівництва (м. Санкт-Петербург, 1894), Всеросійській промислово-художній виставці (м. Нижній Новгород, 1896), Київській сільськогосподарській та промисловій виставці (м. Київ, 1897), II Всеросійській виставці садівництва (м. Санкт-Петербург, 1898) та ін.

На Міжнародній виставці садівництва (м. Санкт-Петербург, 1894) експозиції училища було представлено поруч 3 Імператорським С.Петербурзьким Ботанічним Садом, Московським Сільськогосподарським Інститутом та Імператорським Нікітським Садом. Того ж року наукові розробки та досягнення училища 3 повним розмахом демонструвалися на урочистостях із приводу святкування 50-річчя заснування Головного училища садівництва.

Висновки. Уманське училище землеробства i садівництва, як спеціалізований заклад середньої сільськогосподарської освіти, пройшло складний шлях свого розвитку, зазнало декількох реорганізацій та перебудов у навчально-практичній структурі. Проте, визначальною його особливістю в системі інших фахових закладів такого типу була підготовка висококваліфікованих спеціалістів (вчених-управляючих і вчених-садівників), викладачів для нижчих сільськогосподарських закладів, службовців установ аграрної сфери та досвідчених науковців у галузі садівництва та рільництва, 
цілком задовольняючи, насамперед, місцевий попит на фахівців у галузі сільського господарства.

За високі показники в науковій та сільськогосподарській діяльності, зразкові експонати Уманське училище землеробства i садівництва неодноразово (в різні роки) було нагороджено Золотою, Великою срібною та Бронзовою медалями, почесними відзивами, похвальними листами та ін. нагородами. процесі училища велике значення приділялося науковим дослідженням: воно було одним із засновників дослідної справи не лише в регіоні, а й в Україні. А навчально-виробнича і науково-дослідна база училища була найбільшою в імперії. Впродовж останніх 175 років Уманський національний університет садівництва є флагманом вітчизняної аграрної освіти.

\section{СПИСОК ВИКОРИСТАНИХ ДЖЕРЕЛ І ЛІТЕРАТУРИ}

Власюк, 1941 - Власюк П. Історія створення та розвиток інституту в м.Умані. Умань, 1941. 124 с.

Карасюк, 1994 - Карасюк I.М. Уманський сільськогосподарський інститут. К.: Вища шк., 1994. 202 с.

Карасюк, 1994 - Уманський сільськогосподарський інститут (1844-1994): 150 / уклад.: І.М. Карасюк, М.Ю.

Замаховська; перекл.: Т.Г. Сухомейло та ін. К.: Вища школа, 1994. 88 с.

Костюк, 2005 - Костюк М.В. 3 історії становлення нижчої сільськогосподарської освіти на Черкащині // Часопис української історії. К., 2005. Вип. 2. С. 32 - 35.

Кравець, 1994 - Кравець В.П. Історія школи і педагогіки. Курс лекцій: навчальний посібник закладів та університетів. Тернопіль, 1994. 358 с.

Кузнець, 2000 - Кузнець Т.В. До історії освіти на Уманщині (XVIII - початок XX століття). К.: Науковий світ, 2000. 35c.

Москальский, 1881 - Москальский Н. Сельскохозяйственные учебные заведения ведомства Министерства государственных имуществ. Средние сельскохозяйственные учебные заведения. СПб., 1881. Вып. II. - 88 с.

Программы, 1888 - Правила и примерные программы для практических занятий учеников земледельческих училищ. СПб.: Тип. В. Киршбаума, 1888. 39 с.

Сафронов, 1910 - Сафронов М.Е. Уманское училище садоводства и земледелия. СПб.: Тип. В. Киршбаума, 1910. $80 \mathrm{c}$.

Сборник, 1899 - Сборник сведений по сельскохозяйственному образованию. Постановления по сельскохозяйственным учебным заведениям за время 1836 - 1899 гг. СПб., 1900. Вып. III. 415 с.

Сборник, 1900, - Положение о преобразовании Главного училища садоводства в Умани и Императорского Никитского Сада с находящимися при нем Магарачским училищем виноделия от 8 мая 1868 г. // Сборник сведений по сельскохозяйственному образованию. Постановления по сельско-110 хояйственным учебным заведениям за время 1836-1899 г2. СПб.: Тип. В. Киршмбаума, 1900. Вып. III. С. 169-171.

Устав, 1895 - Устав земледельческих училищ // Сельскохозяйственные учебные заведения, подведомственные департаменту земледелия в конце 1895 г. СПб., 1896. С. XIII-XVI.

\section{REFERENCES}

Vlasiuk, 1941 - Vlasiuk P. Istoriia stvorennia ta rozvytok instytutu v m.Umani. [History of creation and development of the institute in Uman]. Uman, 1941. 124 s. [in Ukrainian].

Karasiuk, 1994 - Karasiuk I.M. Umanskyi silskohospodarskyi instytut. [Uman Agricultural Institute]. K., 1994. 202 s. [in Ukrainian].

Karasiuk, 1994 - Umanskyi silskohospodarskyi instytut (1844-1994). [Uman Agricultural Institute]. K., 1994. 88 s. [in Ukrainian]. 
Kostiuk, 2005 - Kostiuk M.V. Z istorii stanovlennia nyzhchoi silskohospodarskoi osvity na Cherkashchyni. [From the history of the formation of lower agricultural education in Cherkasy region]. Chasopys ukrainskoi istorii. [A journal of Ukrainian history]. 2005. 2. 32 - 35. [in Ukrainian].

Kravets, 1994 - Kravets V.P. Istoriia shkoly i pedahohiky. Kurs lektsii: navchalnyi posibnyk zakladiv ta universytetiv. [History of school and pedagogy. Course of lectures: educational manual of institutions and universities]. Ternopil, 1994. 358 s. [in Ukrainian].

Kuznets, 2000 - Kuznets T.V. Do istorii osvity na Umanshchyni (XVIII - pochatok KhKh stolittia). [To the history of education in the Uman region (XVIII - the beginning of the twentieth century)]. K., 2000. 35 s. [in Ukrainian].

Moskalskyi, 1881 - Moskalskyi N. Selskokhoziaistvennыe uchebnыe zavedenyia vedomstva Mynysterstva hosudarstvennыkh ymushchestv. Srednye selskokhoziaistvennыe uchebnыe zavedenyia. [Agricultural educational institutions of the Ministry of State Property. Secondary agricultural educational institutions]. SPb, 1881. 88 s. [in Russian].

Prohrammы, 1888 - Pravyla y prymernыe prohrammы dlia praktycheskykh zaniatyi uchenykov zemledelcheskykh uchylyshch. [Rules and sample programs for practical training of students of agricultural schools]. SPb, 1888. $39 \mathrm{~s}$. [in Russian].

Safronov, 1910 - Safronov M.E. Umanskoe uchylyshche sadovodstva y zemledelyia. [Uman School of Horticulture and Agriculture]. SPb, 1910. 80 s. [in Russian].

Sbornyk, 1899 - Sbornyk svedenyi po selskokhoziaistvennomu obrazovanyiu. Postanovlenyia po selskokhoziaistvennыm uchebnыm zavedenyiam za vremia 1836 - $1899 \mathrm{hh}$. [Collection of information on agricultural education. Regulations on agricultural educational institutions during the period 1836-1899]. SPb, 1899. III. $415 \mathrm{~s}$. [in Russian].

Sbornyk, 1900, - Polozhenye o preobrazovanyy Hlavnoho uchylyshcha sadovodstva v Umany y Ymperatorskoho Nykytskoho Sada s nakhodiashchymysia pry nem Maharachskym uchylyshchem vynodelyia ot 8 maia $1868 \mathrm{~h}$. [The provision on the transformation of the Main School of Horticulture in Uman and the Imperial Nikitsky Garden with the Magarach Wine-Making School dated May 8, 1868]. Sbornyk svedenyi po selskokhoziaistvennomu obrazovanyiu. [Collection of information on agricultural education]. SPb, 1900. III. 169-171. [in Russian].

Ustav, 1895 - Ustav zemledelcheskykh uchylyshch. [Charter of agricultural schools]. SPb, 1895. [in Russian]. 